\title{
Contested Space of Transborder Fishing in Timor and Arafura Seas
}

\author{
Shiskha Prabawaningtyas \\ Paramadina Graduate School of Diplomacy \\ Universitas Paramadina \\ Corresponding author: shiskha.p@gmail.com
}

Received:

24 April 2017

Accepted:

30 May 2017

\section{Abstract}

The continuity of Indonesian transborder fishing activities into Australian Fishing Zone (AFZ) highlights the rooted dispute of maritime border when contested space of boundary shared by local, state and international actor is confronted. Therefore, the prevailing of multilayer perspective of maritime boundary should not be easily neglected. The colonial project in early 19th century in Southeast Asia that initiated the foundation of modern state-formation had challenged the prior-political and economic construction of the region, specifically on the issue of territoriality. The modernization of shipping and fishing activities of which relied on technology and capitals had generated political and economic competitions and later persuaded state's actors of applying the strategy of the territorialisation of the sea in order to ensure control. Unavoidably, securitization of transborder fishing became preferable solution. Transborder fishings are further subjected into state control relied on territorial sovereignty.

This paper examines the transformation of transborder fishing in Timor and Arafura Sea to demonstrated the contested space of which interplayed by local, state and international actor. State regulations had transformed transborder fishing into political space of authority competition relied on territorial sovereignty, while socio-cultural heritage reminds exploited within fluid space of livelihood survival when state function is just absent.

Keywords: Transborder activities; Deteritorialization; Traditional fishing; Arafura Sea.

\section{Introduction}

Baco Muin, a 51 year old Bajonesse living in Bokori village, Kabupaten Konawe, Southeast Sulawesi took the risk of transporting migrants to Australian waters in order to ensure the educational fund for his children. Being offered the payment of Rp 35 million, it was a very lucrative deal against the decreasing price of shark fins 
fishing. Being detained in Australia prison at Darwin for illegal shark fins fishing in Australia Fishing Zone did not stop Jusri, 32 years old Bajonesse living in Mola village, Kabupaten Wakatobi, to take the offer of transporting migrants to Australian water again, although it turned out to be cancelled after the boats suffered a machine breakdown. It is a secure feeling in experiencing Australian's treatment that contributes to his calculation to take the offer. These two cases do not only illustrate the transformation of Indonesian transborder fishing in Timor and Arafura Seas, but also confirm the complexity on how "boundaries" is such a contested space shared and interpreted by locals, states and international actor. State border should not be treated in contained physical space, but also social space that has been established even before the delimitation of that modern state border. Joel S. Migdal (2004:5-6) asserts the prevailing checkpoints and mental maps that attached to boundary.

This paper examines the transformation of transborder fishing in Timor and Arafura Seas to demonstrated the contested space of which interplayed by local, state and international actor. State regulations had transformed transborder fishing into political space of authority competition relied on territorial sovereignty, while sociocultural heritage reminds exploited within fluid space of livelihood survival when state function is just absent.

\section{Results and Discussion}

\section{The Transformation of Transborder Fishing in Timor and Afarura Seas}

Transborder fishing, used in this paper, refers to fishing activities that is conducted across state border of modern nation-state in the wake of decolonization in the post of World War II. While Australia has gained its autonomy of governed from the British colonial in 1901, Indonesia just declared its independent as new nation-state of which inherited the administration of the Dutch colonial in August 1945. It was only in December 1949 that Indonesia gained de jure recognition as new nation-state of which Australia was one of the strong supporters, beside India, of its diplomatic struggles in United Nations, an international regime of world order in the post of World War II. Therefore, transborder fishing mainly refers to fishing activities across Australia and Indonesia maritime's boundary that lies in Arafura and Timor Seas.

Arafura and Timor Seas geographically situate between the southern part of Indonesia and the northern part of Australia. Lying in adjacent to each other as illustrated in below map, the seas linked Indonesia archipelago with Australia. Timor Sea lies between the southern part of Indonesian province of East Nusa Tenggara and two states of Western Australia and Northern Territory, while the Arafura Sea position between Indonesia province of Maluku and West Papua and state of Northern Territory and Queensland. The Torres Strait links Australia and Papua New Guinea frequently used by Australian vessel to approach Arafura Sea. Approximately covers the surface area of $610,000 \mathrm{~km} 2$ or $240,000 \mathrm{sq} \mathrm{mi}$, Timor Sea has number of reefs, strands of uninhabited island and rich hydrocarbon reserves. Having its deepest depth of 3,200 m or around 10,500 feet, the part of Timor gap is famous known as riches natural resources of oil of which later became the strongest 
political economy magnitude of border conflict in 1970s. The length of Arafura Sea is about 1,290 km, while it has $560 \mathrm{~km}$ of width. Its depth in average is about $50-80 \mathrm{~m}$ (165-265 feet) while it increases toward the west. Arafaura sea is known as one of the place in Southeast Asia where strong seasonal upwelling ${ }^{1}$ take place despite in Banda Sea (Butcher 2004:12) that influence the food chain system determining fish stocks (see map in Figure 1 below).

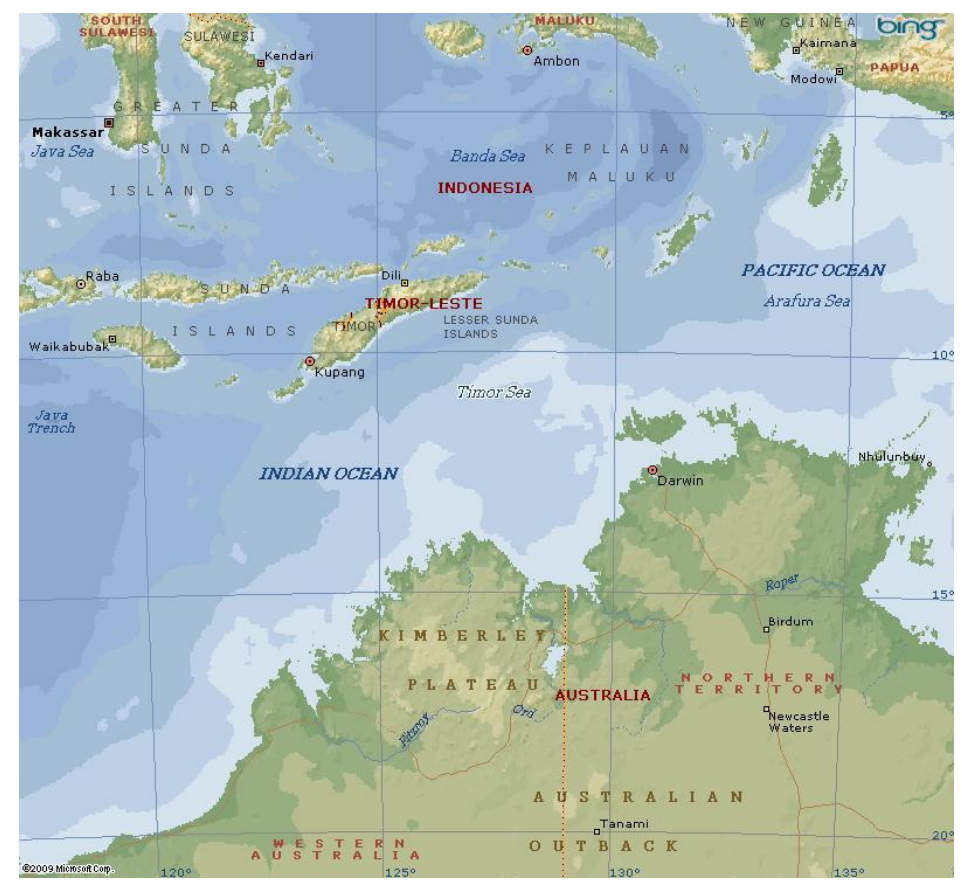

Figure 1. Map of Timor and Arafura Sea

Source: http://easttimorlegal.blogspot.de/2011/01/timor-sea-program-amendment-gets-ok.html

As political decision, maritime boundary between Australia and Indonesia had only been imagined, established, negotiated and delimited between two states after Australia declared its sovereignty over continental shelf in 1953 and followed by Indonesia through Djuanda declaration on 13 December 1957 imposing the concept of archipelagic states. In concomitant with the ongoing negotiation to establish new international regime on the law of the sea under United Nations Conference since 1958, Australia and Indonesia entered bilateral negotiation to delimit maritime boundary despite of unilateral claimed maritime boundary by each state such as Law No.4/1960 on Indonesia waters, the expansion of Australia Fishing Zone (AFZ) from $3 \mathrm{~nm}$ to $12 \mathrm{~nm}$ in 1968 and from $12 \mathrm{~nm}$ to $200 \mathrm{~nm}$ on 1 November 1979 and Indonesia Exclusive Economic Zone in 1980. On 9 October 1972, Australia and Indonesia signed an agreement of establishing certain seabed boundaries in the area of the Arafura and Timor Seas. Confronted with continuous "illegal" transborder fishing activities of Indonesia fishermen into AFZ, both countries agreed to compromise of recognizing the Indonesian traditional fishing right. Under the Memorandum of Understanding between the Government of Australia and the Government of the

\footnotetext{
${ }^{1}$ Upwelling is one the processed when nutrient (element needs for the growth of phytoplankton a part of source of food in marine ecosystem) are brought to the upper level where there is sunlight.
} 
Republic of Indonesia Regarding the Operations of Indonesian Traditional Fishermen in Areas of the Australian Exclusive Fishing Zone and Continental Shelf signed in 1974, Indonesian fishermen were allow to keep fishing in limiting area within the $12 \mathrm{~nm}$ territorial sea adjacent to Ashmore and Cartier Islands, Seringapatam Reef, Scott Reef, Browse Island, and Adele Island in subsistence level. Later, the regulation was named as MOU Box 1974. It is clear that transborder fishing become the keys concept to understand the complexity of problem emerges Timor and Arafura Seas. To sum up, the physical map of maritime boundaries between Australia and Indonesia imagined and visualized in Figure 2 below.

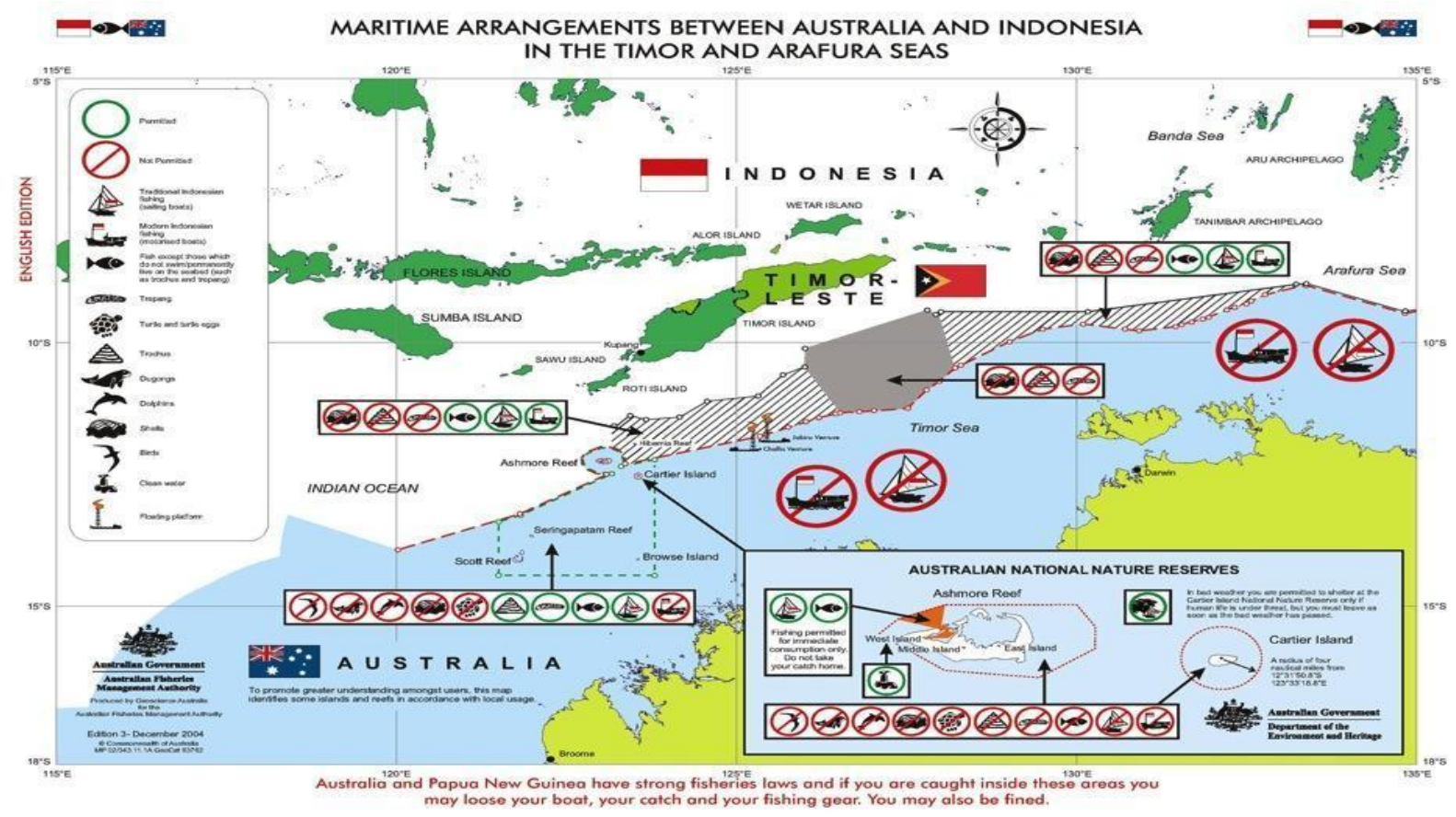

Map 2. Maritime Agreements between Australia-Indonesia in the Timor and Arafura Seas. Source: Stacey, 1999:341.

Transformation of transborder fishing will be to be examined through four aspects relating fishing activities (Butcher 2004: 1-2). First is the object of what and how to be caught. It strongly relates to the application of technology of fishing vessels and gears. Secondly, it concerns about the volume of the catches. The third is the subject who conducting fishing activity. Fourth is the space or location of the fishing ground and the time or the prevailing fishing regime in certain fishing ground in order to answer where and when fishing activity is taking place. The transformation is basically triggered by the expansion of the function of the sea from mainly porous of commerce and market network into centre of state security, resources extraction, environmental protection and humanitarian responsibility. Consequently, the more function attached to the sea, the more set of interests and interpretation prevail.

I argue that it is territorialisation of the sea and the industrial revolution and that transform the sea's function. The colonial project in early $19^{\text {th }}$ century in 
Southeast Asia that initiated the foundation of modern state-formation had challenged the prior-political and economic construction of the region, specifically on the issue of territoriality. The modernization of shipping and fishing activities of which relied on technology and capitals had generated political and economic competitions and later persuaded state's actors of applying the strategy of the territorialisation of the sea in order to ensure control. Unavoidably, securitization of transborder fishing became preferable solution. Transborder fishings are further subjected into state control relied on territorial sovereignty.

Indonesian fishing activities to AFZ had rooted since $18^{\text {th }}$ century when Maccassan voyage had reached Australian coast for trepang collection to satisfied Chinese market. Yet, the inception of British political and economic interest in Australia had forced the abolishing of Macassan voyage and marginalized the local and non-state fishing activities. The expansion of Japanese shipping and fishing activities in Indonesian water in 1880s gave further pressure to local fishing activities. Forcedly, local and non-state fishing activities occupy a peripheral position against state-sponsored fishing activities. Territorialisation of Timor and Arafura Sea both by post-colonial state Indonesia and Australia had made transborder fishing activities under strong state's regulation both on the subject of access to fishing ground and the use of fishing gears. On one hand, immigration approach unavoidably made transborder fishing fall into criminalization if violations are found. On the other hand, the existence of market demand for marine products operates beyond the logic of geographical space of state's territorial sovereignty. Historical legacy and traditions are often used to justify today "illegal transborder fishing" by the locals.

In colonial period, fishing activities in Timor and Arafura Sea were gradually intervened and regulated by the colonial state and later triggered diplomatic confrontation between the Dutch and British Empire. This course of action was mainly motivated by two circumstances. First, it is territorialisation of the sea by (colonial)-state (Adhuri \& Visser 2006: 114-115). The early 19th century marked the territorial expansion of the Dutch and the British to consolidate their colonial sovereignty by encroaching politic of mapping to subjugate local-indigenous political authority into colonial administration and defining state border to solve their conflict of competition (Cribb 2000). Fishing gradually was not only subjected to taxation for state revenue, but also investment and subsidy for expanding colonial economy. Secondly, the introduction of fishing technology was internationally applied and spread. The invention of machine boats and modern fishing gear in $18^{\text {th }}$ and $19^{\text {th }}$ century had inevitably forced modernization of fishing activity (Butcher 2004). New fishing grounds are opened, variety of catches is expanded, volume of catches is increased, and more state regulations are applied.

Fishing activities was later challenged by the expansion of sea exploration as well as environmental activitism for sustainable development. The right of coastal and archipelagic state to claim and exercise authority within Continental Shelf (CS) and Exclusive Economic Zone (EEZ) is internationally acknowledged after the introduction of Geneva Convention in 1958 and the United Nations of the Law of the 
Sea (UNCLOS) in 1982. This international regime has further strengthened the territorialisation of the sea by state, not only for exploiting the marine resources both fishes and minerals, but also for ensuring sustainability of sea ecosystem. Soon, this newly state centric regulation prove to create loophole in anarchic nature of world system because of the divergence interpretation to the means on how to exercise the sovereignty right in opposite to the right to be sovereign on the sea including in Timor and Arafura Sea. State interest remains determining on how the act of fishing within the CS and EEZ should be regulated. In Timor Sea, Indonesia and Australia confront with overlapping claim of EEZ as the length of the area is less $424 \mathrm{~nm}$ from the outer limit of their territorial sea and the preference of Australia to use the principle of prolongation of sea bead under CS than the equidistance of EEZ arrangement. This regime has further clustered the sea into state control of territorial jurisdiction by delimiting seas based on water column and seabed prolongation, for example the newly concept of Australian Fishing Zone (AFZ). Consequently, this arrangement of who, what, how and where the act of fishing can be legally conducted become sources of transborder fishing conflict. Diplomatic confrontation frequently resumes between Indonesia and Australia in early 2000s as the push of boat people has complicated the intention of both states to regulate Indonesian transborder fishing activity in Australian Fishing Zone.

\section{Expansion of Fishing Ground: 1800s to 1940s}

The network chain of transborder fishing in these seas is determined by the species of marine resources to be collected and the prevailing demand of distant market. As will be discussed below, transborder fishing more likely falls under industrial type of fishing activity than artisanal. It simply means that fishing activity is more motivated by export-driven market than to fulfil the need of own-household and domestic market demand. The agency of transborder fishing network was actually established when the fishing vessel always employed local labour normally as the collector species, while the owner of fishing vessel and the end-consumption of the product situate far away beyond the fishing grounds. Later, in early $20^{\text {th }}$ century, joint ventures of fishing company between foreign and local investor become a customary practice in confronting with the need of fishing license imposed by the colonial's state authority.

The first recorded transborder fishing in Timor and Arafura Sea of which began in $17^{\text {th }}$ century is the collection of trepang ${ }^{23}$ to meet the distant market of Chinese cuisine. The expansion of the Makassarre to seek new resource and fishing ground partly had been forced by the VOC's monopoly policy on spice's trade that destroy the role of Makassaree under the Sultanate of Gowa. C.C.MacKnight's study (1972; 1976) concludes that Indonesian fishermen mainly from Makassar had been sailed all

${ }^{2}$ The term trepang comes from Malays words, teripang. Other might named bêche-de-mer from Portuguese word bicho da mar or sea worms. It is also known as sea cucumber or sea slugs. Trepang is echinoderm from the class of Holothuroidea that live in sea floor or swallow water that exposed to low tide shallow water in mostly Southeast Asia's sea. One Dutch scientist once had collected names applied for this animal and listed about 112 throughout Indonesia (MacKnight 1976:3). Its length is usually around 10 to $50 \mathrm{~cm}$, although one might get about $1 \mathrm{~m}$ or more. The colour of trepangs would have such variety and depend of the species from black, white, grey, brown blue or red. 
the way from south Celebes (Sulawesi) for collecting trepang near the coastal between Cobourg Peninsula and the Sir Edward Pellew Group from around 1720 to 1906. The land of these coastal areas was called as Arhnem Land or today Northern Territory of Australia. The commonly visited site was Groote Eylanda, while the visit to Melville, Bathurst and the Wellesley island was not frequent. It is not coincident that Arhnem Land was later part of the first British's colony established in 26 January 1788 following Captain James Cook's first visit in 1770. Trepang industry might have invited such interest to open colony settlement after the expedition of Willem Janszoon Blaue in 1606 and 1618, the first European recorded journey to Australia who had served as governor of the Netherlands East Indies in 1603-1616 including act as governor of Fort Henricus in Solor. As navigator, his journey map has provided knowledge of navigation to reach Australia continent for European's expansion.

Calling the activity as the Voyage of Marege (named used by the Makassan to call Arnhem Land), MacKnight explains that this fishing activity also invited the involvement of local resident, the Aborigine, and later known as the first fishing industry in Australia (Worsley, 1955:2 as quoted in Russel, 2004:1). The locals called the Makassans as "Manggadjara" or "Munanga". Throughout the years, trepang industry had been developed considerably or in word of MacKnight that the size, stability and sophisticated was impressive (1976:1). Matthew Flinders, a British navigator who conducted survey of Gulf of Carpentaria and Cape Wilberforce, the northeastern of Arhnem Land, discovered six praus or sailing vessel from Macassar from South Celebes on 17 February 1803 as part of seasonal voyage collecting for trepang (MacKnight, 1976:1). Although people from this voyage are mentioned as Malays by Flinders, MacKnight suggest that most of the fishermen were actually Makarasse. Yet, the term Maccassan itself, as MacKnight argues, do not exclusively refer to racial or ethnicity affiliation because other ethnic such such Buginesse and Bajo might also had joined this voyage (1976:1). This trepang industry was later expanded in several different part of the Australia costal despite of the Arhnem Land. The Makassans had also seen in the Kimberley Coast of Western Australia, south of Cape Londonderry of which called by Kayu Jawa by them (MacKnight 1976:33), and Queensland. MacKnight (1976:29) estimated that there were around 1000 Makassan's fishermen doing the fishing in Australian coast in the $19^{\text {th }}$ century.

The route of this Marege's voyage to collect trepang from Australian coast in colonial period was identified to take at least six path of navigation (MacKnight 1976, Fox 1998, Stacey 1999 and Russel 2004) before reaching back the final destination of Makassar port to load their catches and later taken to Chinese market. First route started from Makassar passing through Banda Sea toward Kei and Aru islands in Arafura sea, and finally anchored in Arnhem Land or Groote Eyland. Second route was from Makassar sailing through Alor Island and the eastern part of Timor islands before heading right direction to Melville islands or Arnhem Land. Third is the same route taken with second route, but after reaching the eastern part of Timor Island they took left direction to Kimberly coast. The fourth began from Makassar crossing Banda sea to the eastern part of Flores island through Flores strait, sailing down to Rote strait between Roti and Timor island or mostly anchored in Kupang port before continue the voyage to Kimberley coast. Between Kupang and Kimberley Coast, the voyage frequently anchored in Ashmore islands or reef to add supplies of water. Fifth route was identified taking the same path of fourth route but after anchored in Ashmore reef or other nearby island, the voyage would take to left and sailing down to reefs of islands in northwest of Kimberly coast. The sixth path would started the 
journey from Makassar to Madura island, passing through the Sape strait between the eastern edge of Sumbawa and Komoda island, sailing down to coastal water of Sumba Islands passing through Sumba strait to reach Rote island, and later continue heading to the Ashmore reef before finally reached the reefs of surrounding islands of northwest of Kimberly coast. They took the advantage of wind power of east monsoon around the month of August to December. Those routes of voyages that took months would usually make a visit in certain land for reloading logistic and seeking labour supports (Fox, 1977). For example, the fourth and fifth route would anchored in Flores island and Kupang to took labour, while loading food supplies in Ashmore reef before heading to Kimberley coast (Stacey 1999). In 1728, VOC's officer in Kupang wrote that he had encountered Bajau people sailed heading to Northern Australia for collecting trepang (McKnight, 1976). Even in 1750, VOC's document recorded the issuance of letter to Maccassan fleet arriving in Timor to get passage before sailing to Rote island (Fox, 1977).

Captain Phillip King, for example, also witnessed a fleet of perahu in Timor in 1927 and was informed that around 200 perahu had sailed annually from Makassar to eastern Arnhem Land (1827:135-6 as quoted in Russell, 2004: 6-7). Other study suggests the possibility of the presence of people from Timor and Aru in Makassan transborder fishing practices (Berndt \& Berndt, 1954:40 as quoted in Russell, 2004:8). The path of passing through transit points such as islands of Aru, Kei, Madura, Flores, Alor, Sumba, Sumbawa, Timor, and Rote played significant function to the establishment of network chain to reproduce knowledge about fishing voyage to Australian coast. Customarily, it was through oral tradition that information about marine resources and navigation was inherited among Indonesian fishermen. In following years, Kupang and Pepela in Rote Island became some of the starting of port of transborder fishing to Australia Fishing Zone (AFZ) to collect turtles and shark fishing.

In 1906, the Makassar trepang industry collapsed after the Australian government officially stopped it after serial of policies in previous years. The official reason was the growing threat of disease and alcohol brought by Makassan. Yet, some observers believe that the closing of Makassar's trepang fishing motivated by the nationalization of the industry (Berndt \& Berndt, 1954: 78 as quoted in Russell 2004: )including the growing competition with shell-pearling industry that was started around 1860s in Kimberley coast. There is written records telling story about Captain Francis Cadell, Australian fishing vessel's owner, who in in 1867 had persuaded the South Australia authority to stop Makassan fishing vessel from collecting trepang (Mullins, 2001: 9). Captain Cadell was known as one of Australian fishing vessel's owner that involved in shell-pearls industry. Previously, in 1863 South Australia annexed Northern Territory where most activities of Makassan fishing vessel colleting trepang were operated. The discovery of silver and copper in South Australia in 1840s and the opening of gold industry in 1851 in Victoria after its separation with South Australia colony might contribute to pressure of nationalizing the trepang industry. Mac Knight suggests that the actual reason relates to the colony authority to protect their coastal area and provided favourable incentives to the pastoral development that was more interested to mineral-land industry and shellpearls. The growing of diverse industry in Australia had created the need for labour supply. Consequently, it invited the state's authority to regulate industry activities including labour. It was labour issues of which later drawn common interest of colonies to established a federal state of Commonwealth Australia under the British Empire in 1901 and enacted its constitution of governing including Immigration 
Restriction Act 1901 (Schloenhardt, 2003: 55). This political constellation had promoted such confident for Australian government to protect their territory against foreign activities in the name of national interest.

As mentioned above, shell-pearl industry was the second fishing industry developed in Australia of which involved transborder activities. It was industrial revolution in mainland of British Empire that had opened new market of shell-pearls. Not only that shell-pearl valued for its pearls for jewellery, but also as rough commodity for buttons and other fancy ornament. Buttons industry was developed as demand for Victorian's style fashion widespread among British community of which later expand to United States. It was part of Cultural Revolution in modernization world. The shell-pearls industry was immediately established and become the second of most important transborder fishing industry in Timor and Arafura Sea than trepang. In contrast to trepang industry, shell-pearl industry was developed in favour of incentives provided by the impact of industrial revolution and the opening of Suez Canal. It was initiated by Australia and British capital. The industry soon displaced the artisanal type of Aboriginal fishing activity of collecting shell-pearl for limited household's demand into a highly commercialised and exportorientated industry for distant market on one hand. While on the other hand, it stimulated competition to prevailing trepang industry for its overlapping location of its fishing grounds.

Ronald Moore (1994) concludes that Australia shell-pearl was firstly set up in Shark Bay (around $540 \mathrm{~km}$ from Perth) and North West of Nickol Bay (1000 km from Perth) after the expedition of Lieutenant Grey in 1837-1938 to Nickol Bay. This area was initially part of New Holland that was established as British colony in 1825, but later named as Western Australia in 1832 (in 1829 it was called Swan River Colony). Later in 1861, he returned to the Nickol Bay and start to collecting shell-pearl with financial support from Royal Geographic Society and British Government. Later in 1864, flow of pastoralist had flooded into Nickol Bay. An advertisement in newspaper on 22 October 1866 about shell-pearl had invited more interest for its high return profit. The species collected in Shark Bay was identified as margaritifera carcharium of which live densely but limited in swallow water, while in Nickol Bay, it was margaritifera maxima lying in deeper water with large amount of supply. The margaritifera maxima values more expensive compare to margaritifera carcharium in the market's price. In 1867, it was reported that one vessel named Tays could collected 2 tons per 4 days and valued about 1000 Pounds. In 1868, there were around 10 vessels operating in Nickol Bay collecting shell-pearls. The Aboriginal people were recruited to dive reaching deep water in order to satisfy market demand. The highly commercial scale of this industry could be seen not only from the application of modern fishing vessels and gears, but also the expansion of labour to recruit Asian labour mostly Malays and Japanese than only Aborigine. Asian divers were acknowledged for their skill and lung capacity for having able to dive below the sea depth of 12 metres (Butcher 2004). It was pastoral development that accelerates the volume of catches and expand the size of the industry.

Although concern over stock depletion had daunted the industry in 1870, conversely shell-pearl industry grew even more massive. They started to recruit Malays divers. In 1875, it was recorded that around 1000 Malays employed in shellpearl collection in this area. Yet, received report of bad treatment for the Malays's labour had made the Dutch authority prohibited the further employment of which the application decreased the number of Malays working in this shell pearl. In 1887, more Japanese divers were recruited along with the introduction of diving dress and 
the pressure of more regulated condition for Malays labour proposed by the Dutch authority. It was Augutus Siebe who invented the technology in England in 1839 (Butcher 2004:125). The diving gear consist of diving dress made of waterproof canvas, a helmet, a corselet, weighted shoes, a hand pump, a rubber hose and a lifeline. (Butcher 2004: 125). A rubber hose was connected to hand pump to deliver the air to the helmet, while the hand pump was placed and operated on board. The diver was tugged by a rope function as lifeline. Although the shell-pearls industry in Nickol Bay had still operated, new fishing ground was already opened in Broome in 1880s. In Broome, new fishing technology was firstly introduced using floating station and apparatus method (diving dress and mechanical pump of compressor) in order to extend time of diving for more collection in deep water. Later, other new fishing ground opened in Queensland especially around the Torres Strait when Australian shell-pearl industry new technology of diving gear. At this point, shellpearling fishing had expanded their fishing ground from swallow into more depth water and move further distant from the coastal area. Due to attractive economic values of the industry, the colony authority of Western Australia and Queensland applied high taxation to the industry in 1889. In 1914, there were 1115 Japanese, 585 Malays and 247 Koepangers who worked at shell-pearl industry in Western Australia (Martinez 2009: 98) Ronald Moore (1994) and Steve Mullins (2001) believed that the issuance of high taxation to shell-pearling had further forced Australian vessel of shell-pearls collection to seek new fishing ground in addition the threat of depletion on available known fishing ground in Australia. In addition, the publication of British naturalist, Alfred Russell Wallace's expedition to the Malays's archipelago between 1854-1862 also promoted a wide spreading knowledge about the abundance natural resource along this strands of island including shell-pearls in Aru and Kei island. In the word of Wallace

The bottom was absolutely hidden by a continuous series of corals, sponges, actiniae, and other marine production, of magnificent dimensions, varied forms and brilliant colours. The depth varied from about twenty to fifty feet, and the bottom was very uneven, rocks, and chasms, and little hills and valleys, offering a variety of stations for the growth of these animal forests. In and out among them moved numbers of blue and red and yellow fishers, spotted and banded and striped in the most striking manner, while great orange or rosy transparent floated along near the surface (Wallace 1890: 226)

Year later in early 1880, several attempts of Australia expedition had been conducted sailing to Aru island for example the story of fishing vessel Jessie (1872) and Franz (1872). In between 1880-1881, Clara Crawford, another Australia fishing vessel was forced out the left Aru island. As a counter response, the Dutch built a post in Aru island. Previously, in 1828, the Dutch also had built Fort du Triton and declared Makassar, Ambon, Bandanera and Ternate as free port. In 1878, it was reported that five Australian fishing vessel namely Onward, Good Luck, Ajelia and Caft had been forcedly anchored for three year doing other possible activities in Makassar after denied of collecting shell-pearl before paying tax to the Dutch. Another Australian fishing vessel under the command of Captain Cadell was ended by him getting killed by his own crew in their attempts of harvesting shell-pearl in Kei Island in 1879. The operation of Australian fishing vessel in Arafura Sea heading to Aru Island invited strong response from the Dutch government. One of the 
reasons was believed to be related to information of the bad employment condition of Indonesian recruited by the Australian fishing vessel. It was only in 1886 that Australian fishing boats had anchored in Aru Island in their way back from Kimberly area to Torres Strait after their collection of shell-pearl there were still not satisfied their target of beneficial return. Since then, there was a discussion in Dutch government whether orang kaya in Aru (a kind of rich and community leader) could legally transfer their communal rights of fishing to foreigner, respectfully to Australian fishing vessel.

In 1891, the Dutch concern over Australian shell-pearl fishing vessel came into tested. Steve Mullins (2001) had comprehensively described episode of the Dutch and British rivalry over access to shell-pearl fishing ground. Confronting to high tax of shell pearl issued by Western Australia and Queensland under the extra-territorial Act of 1889 and the amendment of 1875 Kindnapping Act that prohibited employing Pacific islander on oneh hand, while on the other hand shell-pearls and pearling industry in England grew more lucrative, a London jewellery entrepreneur, Edward Streeter decided to involved into this fishing industry. His Pearling \& Trading Company, Ltd. legally registered in British set up a fleet of Sree Pas-Sair consists of Mavis and Flowerdale fishing vessel that soon would despatched to Aru island. They employed around 61 Solorre divers recruiting in Kupang. Possessing an elite circle, the company's chair of board director, T.H. Haynes lobbied the British's Foreign Secretary, Lord Salisburg in 1891 by writing him about his company intention to sail to Aru island for collecting shell-pearl and saying about the presence of Dutch vessel of which probably operated beyond $3 \mathrm{~nm}$ as and to be considered against customary law of High Seas. His action might be strongly motivated by the incident of Costa Rica Packet vessel that was wrongly arrested in Ternate and put into detention in Makassar.

He requested for compensation of protection and cessation from any interference. Yet, Lord Salisburg replied in 28 July 1891 by saying any future stage of affairs should be addressed in the court since the British, in position, to develop friendly colonial relations with the Dutch after border conflict in Bornea (Kalimantan) that came into the signing of the 1891 border agreement. This replied turned to dissatisfy T.H. Haynes by saying neutral position in the situation of possible future conflict would be perceived as invasion to British's right in the High Seas. This kind of physiological warfare on the activities of Australian shell-pearling fishing vessel, to Steve Mullins (2001), created by the perceived image about each other. The Dutch inclined to be in hostile relations as they had seen Australian of being abusive to Malays labour and lawlessness, while Australian had always seen the Dutch authority of being Decay Empire with jealousy and unfairly hoarded resources. The predicted course of conflict actually came to happen. In March 1893, the Dutch resident of Ambon, Baron van Hoevel in Aru, received complaint from Rajah Oejir in Dobo about the work of Mavis. At the time of receiving complaint, the Dutch warship Java was anchored in Dobo.

Responding to the complaint, Hoevel invited Mackellar, the vessel's officer, to 
discuss the matter in the presence of Raja of Oedjir as well. Mackellar explained that the current activities was his second attempt of collection shell-pearl after previously Raja of Oedjir himself had granted him permission in return of receiving payment. He argued that it should not be a problem after the prevailing agreement. Considering his explanation, Hoevel suggested Mackellar to give another payment for his second course of action of which he agreed. But, Rajah had different proposition to completely stop the activity by saying his concern about environmental impacts. The meeting was assumed to reach the agreement of stopping any kind of future fishing activities. On 12 May 1893, O'Kelly, friend of MacKellar sent cable to Hayes about the incident and saying he would keep continuing the fishing activity. Receiving the cable, Hayes wrote again to Lord Salisburg about the act of harassment and required British's protection. The Foreign Office responded by saying that such action could only be done when evident of the harassment was received. Hoevel found that Mavis still kept operating the collection of shell-pearls when later he visited Dobo. This time, it was reported that the payment was made to orang kaya, not the Rajah. Quickly responding to the situation, Hoevel summoned O'Kelly, but this time directly to the Java's warship with the presence of Dobo postholder. O'Kelly claimed that he had paid for the collection in return for permission that had been granted by orang kaya. He testified that Dobo postholder himself who suggest him of asking permission from orang kaya instead of Raja. Further, Mackellar claimed that he had also made payment to Dobo postholder himself for 2 pounds per ton of collected shell-pearl. Highly disturbed by the way Mackellar explained the situation both of his temper and abusive way of behaviour and the accusation of bribery made to his subordinate, Hoevel decided to dismiss the meeting.

Following up the situation, Hoevel sent report to Dutch authority in Batavia that Australia had been showing such complete contempt for the Dutch Authority (Mullis 2001:15). He described the situation that both O'Kelly and Mackellar had intimidated the Postholder; instilled fear into the pro-Dutch population; insulted the Dutch government, and had created the orang kaya by taking more shell-pearl than the actual price they had paid. He also wrote that around 500 Australia boats were expected to arrive from Australia. In turn, Batavia authority had responded the report seriously by instructing the Commander of the Netherlands Indies Navy, Vice Admiral Roell to immediately dispatched Sumatra, Navy Fleet equipped by torpedo trial off Madura. Another two warships, Trompe and Pontianak, had also been dispatched. Examining the situation, Vice admiral Roell suggested that the only possible course of action was escorting the lugger skipper backed to the mother vessels. To completely forced them out the area including the mother vessel that stationed beyond the $3 \mathrm{~nm}$ of Dutch water would impossible, unless a new law would be passed outlawing the act of fishing within the $3 \mathrm{~nm}$ of Dutch water. Roell acknowledged the customary law of $3 \mathrm{~nm}$ and the High Sea.

What actually happened on the incident was unclear. The Northern Territory Times wrote the testimony of Captain Lumsden, from Flowerdale, that they had 
managed to kept situation in order and returned with shell-pearl worth around 3000 Pounds. While the Soer, a newspaper in Batavia, referred Australian as freebooter who doing act of robbery. Although in the fisrt place, Hovel intended to pursue the rights of Aruese over shell-pearl outside the $3 \mathrm{~nm}$ of Dutch water as time immemorial, but the Dutch authority in Batavia opted not to have that position. One of the reasons relates to the 1886 colonial regulation stating that people of Aruese possessed no legal right over shell-pearl beds on the sea water. In addition, The Hague also expected to build a friendly relation with the London. On the follow up of diplomatic communication, both Baron Hoevell and T.C.Hayes admitted that the course of action took place within the $3 \mathrm{~nm}$ of Dutch water. Hayes also added that the shell-pearl collection had only been executed after permission was granted. The state of affair ended by The Dutch authority issued an ordinance No.261/1893 legally claimed the Dutch territorial water of 3nm on 5 October 1893.

After this course of diplomatic tension between the Dutch and British, the shellpearls industry gradually transformed into new arrangement of transborder fishing activities. The operation of Celebes Trading Co. began in 1905 interestingly deciphered this transformation taken from the relationalist point of view. Established in 1905 by James Clark, an Australian entrepreneur, Celebes Trading Co. started the successfully path in fishing industry by incorporating the core concept of transborder fishing activities in term of subject. James Clark had his ownership share at the Pearling and Trading Trading Co. There were a meeting in London with the presence of Edward Street, E.H. Haynes, and A.L.Coventry (Clark's manager) before the established of the new company. Later, James Clark expanded his fishing industry by introducing shared ownership through license and capital share. By registering his company in Batavia, James Clark was able to obtain concession of exclusive right harvesting shell-pearl in Aru's fishing ground from the Netherlands East Indies authority. The initial asset of the company was equipped by 7 schooner fleets consisting of around 115 vessels. Later in 1907, the capital ownership was expanded when his bother A.J. John and local Indonesian, Said bin Abdullah Baadila from Banda joined the industry by operating there more fleets and made the company now possessed 135 vessels collecting shell-pearl in water of northern Arafura sea. The Baadilla family, some Arabs living on Banda Island actually had formed some kind of small company or firm that received concession from the Dutch authority to collect pearl-shell (Butcher 2004: 129). The company also opened a branch office in Dobo, Aru's port, employed around 700-1500 local people and operated until 1916 when this capital consortium finally collapsed. Later, the company established new smaller capital ownership and worked until Pacific War that had forced the company to stop their fishing operation.

The strong gesture of the Dutch colonial to administer and control the fishing activities within their self-view of territorial water had further strengthened by the following serial of ordinance after the one in 1893. After confrontation with the British, the Dutch authority conducted survey that brought facts about the prevailing practice of local authority such as Sultan of Tidore and Ternate, and the Raja in east 
cost of Sumatra (around Riau islands) to possess and exercise exclusive rights to collect pearl-shell, pearl, trepangs and other marine resources. As a response to exercise central authority and impose monopoly, Batavia denied self-governance practice of having own sea territorial in 1902, and issued ordinance no.822/1919 stated that only central government who own the authority and right of regulating sea territorial. Relying on speed and volume, the operation of Japanese fishing vessel that was perceived within the Netherlands East Indies water had triggered a quite wide spread complaint from local fishers. They caught sea bream, scads, tuna, and even sharks by developing mobility to several fishing technique from muro ami, trawling, pursue seining, pole and line and longline fishing. This practice had accumulated pressure to regulating transborder fishing activities mostly refer to the conduct of fishing by non-Dutch subject. As further state's response, Batavia issued another ordinance (No.127/1927) that declared territorial water of the Netherland East Indies was included water within $3 \mathrm{~nm}$ of rocks, reefs, and banks. Further authority on the sea was claimed by the Dutch through the endorsement of the Territorial Sea and Maritime Districts Ordinance no.497/1935. This ordinance introduced a new concept of territorial sea of which is defined as the band of waters around each island and extending out from lines across the entrances to bays and estuaries. The concept referred to both idea of territorial sea and internal waters. In the outbreak of World War II, Batavia again revised the concept and enacted Territorial Sea and Maritime Districts Ordinance No.422/1939 of which defined territorial sea to be measured from the low tide line of each individual islands into 3 nm length.

This shell pearl industry gradually collapsed following the World Word II when new invention of plastic had provided cheap substitution for buttons industry (Butcher 2004:135). Japanese soon started to develop a new pearling industry by adopting technology of genetic engineering to grow cultured-pearls, so that they could reduced the cost of finding traditional pearl-shell deep under the sea water and sustain the volume of the production to prevent depletion and environmental harassment. It was actually a British naturalist of Marine biology, William SavilleKen who firstly invented the technology of breeding cultured-pearls. His working experience as commissioner of fishery in several state of Australia from Tasmania, Queensland and Western Australia from around 1884 to 1895 had brought his interest to pearling as depletion of shell-pearl became the major issue of Australian pearling industry at that time. Yet, it was Tokishi Nishikawa who later made the patent rights of the technique of cultured pearl after learned from Saville-Ken and applied the technique to develop cultured-pearling industry in Japan. The collapse of trepang and shell-pearls industry was later replaced by other marine commodity such as tuna (skipjack and yellowfin), sharks (initially as by catch product of tuna fishing), and scads in Timor and Arafura Sea to meet the opening of new fishing market. 


\section{Securitization of transborder fishing: Post-colonial Indonesia to UNCLOS}

The outbreak of Second World War and Japanese military invasion to Southeast Asia had temporarily destroyed the fishing industry in this area between the years of 1942 to 1945. Many of fishing vessels had been destroyed, the primary of western market was collapsed and the safety of navigation around Southeast Asia water had strongly been under Japanese surveillance. Economic activities including fishing had been discouraged and centralized to supply military logistic of Japanese in Pacific War. As the war finally ended in 1945, economic recovery become the key issue in the postwar rehabilitation and reconstruction including fishery and the expansion of sea exploration. It was the United States through the Truman Declaration who firstly declared the expansion of territorialisation of sea by claiming the sovereignty rights along the prolongation of continental self-seabed on 28 September 1945. Later, the issue had brought states to convene discussing the establishment of the law of the sea in serial of multilateral negotiations in 1958, 1960, 1973 and 1982 under the framework of United Nations system that known as the United Convention on the Law of the Sea. Daunted with the fear of future devastated war, international regime to deter aggressive action of state was established through establishment of United Nations (UN). Relied on respecting state's sovereignty, soon UN became an influential international arena to (de)construct new world order. This international gesture had deepened the territorialisation of the sea under state control.

It was not surprising that later territorialisation of the sea developed into part of national identity as delimiting border in the sea for coastal state become the source of territorial sovereignty. Actually, transborder fishing industry in Indonesian water had already resumed in 1947 when the small Japanese pole-and line fishing vessel was re-established by the Dutch soon after end of the war. Based at Aertembaga, North Sulawesi, several fishing vessels started to caught skipjack tuna near the water for domestic market. In 1950, this company was nationalized by Indonesia authority soon after the signing of Round Table Negotiation in 27 December 1949 when the Dutch recognized Indonesia independent. In 1951, Indonesia also built longliner fishing company to catch tuna at Indian Ocean. Later in 1961, Indonesia built another new pole and line fishing company in Ambon. In 1962, another longliner vessel had expanded into water near Christmas Island catching tunas.

Christmas Island had been under Australia's possession after being transferred from Singapore's possession in October 1957 by British colonial. The British itself annexed the island on 6 June 1888. However, massive scale transborder fishing industry just took place when Japanese fishing company started their longlining operation soon after the lifted of MacArthur Line in $1952 .{ }^{3}$ Motivated by post-war economic recovery and growing domestic market demand, Japanese fishing industry found rich fishing grounds of which included Indian Ocean in the south of Java (Butcher 2004:215). It is important to underline that Japanese fishing industry was

${ }^{3}$ MacArthur Line refer the decree issued by MacArthur the Supreme Commander of Allied Forces in 22 June 1946 to limit the area of which Japan could conduct fishing and whaling activities as the repercussion of War sanction. 
strongly supported by government incentives including subsidy since 1898 under Meiji Japan regime. There were ten longliners and Kaiko Maru mothership began their fishing activities in seas of Celebes, Banda and Moluccas including Sea and Arafura Timor in 1952. While later in 1954, the mothership of Saipan Maru operated in south of Java and equipped with five longliners boats. The revival of Japanese fishing industry in the post-war demonstrates the transformation of transborder fishing practice with more sophisticated system involving mothership which carried smaller boats on its deck of which then later despatched into the water when fishing grounds were found. They would either be towed nor lifted back on deck when started moving to another designated fishing ground (Butcher, 2004:215).

The Japanese mothership's operation is best illustrated below.

The mother ship receives the catches of the fleet on the fishing ground, supplies them with fuel, oil, water, store, bait and ice and keeps in daily radio contact receiving details from them of daily catch, fishing condition, and oceanographical and meteorogical information. The director of the operations advises the catchers of the most suitable fishing areas and arranges the time for each catcher to transfer its catch to the mother ship. He may also direct several of the catcher boats to reach for better fishing area (Beare, et.all 163:14 as quoted at Butcher 2004: 216)

They caught tunas from yellow fin, albacore to southern blue fin along Southeast Asia water in adjacent to Indian oceans. In Timor and Arafura seas, they fished yellow fin tuna. Later in 1957, the operation was confronted by Indonesian declaration to expand the territorial sovereignty based on the concept of archipelagic state of which include Timor and Arafura Sea as internal water.

On 13 December 1957, Indonesia proposed the concept of archipelagic states under the Djuanda Declaration. Indonesia basically would close its internal water mainly straits and seas between islands stretching from Karimata strait in the west to Arafura Sea in the east for the passing of foreign vessels without notification. The concept derives from the point of view that strands of Indonesian archipelagos must be seen as a unity of territory. By proposing the baseline technique, Indonesia would delimit their territorial water by drawing baseline that connected the low-tide points of its front islands; so that internal water inside the baseline referred as the archipelagic water. In return of concession, Indonesia would regulate the act of innocent passage to guarantee the security of united Indonesia archipelago. This declaration was initially motivated to stop the passing of the Dutch warship in Java Sea following the escalation over Papua's campaign with the Dutch. ${ }^{4}$ Although the concept of archipelagic state was soon strongly rejected by many states, yet the concept was later internationally recognized as new law of the sea after almost 25 years of negotiation process under the auspices of UN's system.

Actually in 1961, Philippines followed Indonesia stance of claiming themselves as the archipelagic states as well. Japan quickly condemned Indonesia unilateral

\footnotetext{
${ }^{4}$ Interview with Havas Arif Oegroseno, Indonesian Ambassador to the Belgium and Luxemborg, 19 March 2103 in Belgium.
} 
declaration as violating its traditional fishing right and brought first fishery conflict in post-colonial Indonesia regarding transborder fishing. Indonesia started to detain Japanese fishing vessel that led to serial negotiation. Initially, Japan held the position not the recognize the declaration, when they showed lack of interest to engage with Indonesia's proposal for setting up a joint venture company for tuna's fishing. In their view, signing to an agreement with Indonesia would be seen as a gesture to recognize Indonesia's declaration (Butcher 2004:220). Yet, after series of simultaneous bilateral negotiation, Indonesia and Japan reached compromise that led to the signing of Banda Sea Agreement in 1968. The gradual shifting of Japan's position most probably was influenced by the going intensive negotiation under the United Nations Conference on the Law of the Sea since 1958. The inclination of most state to acknowledge the right of a state to claim continental shelf-seabed under UNCLOS I in 1958 and the ongoing discussion to further regulate claim over territorial sea including fishery right might been assessed by Japan as a shifting international attitude to regulate the sea. The agreement allowing Japan longliners vessel to catch Tuna in designated area of most of Banda Sea, yet excluded the water within 30 miles of Ambon. In return, Japan had to pay amount of fee to Indonesia authority. For Indonesia, the signing of agreement was taken as "de facto" recognition to Djuanda declaration, while for Japan, it was only treated as retribution fee of obligation to report the volume of their catch after entering Indonesian port (Butcher 2004:220). Acting on behalf of Japan's representative, the National Federations of Fisheries Cooperative of Japan and the Federation of Japanese Tuna Cooperative Associations signed the agreement instead of the Japan Government itself. This gesture signalled the reluctant of Japan Government to officially accept the implying recognition to Djuanda declaration. This agreement would later renew every years until 1975 after Indonesia became unsatisfied of which one of the aspect is the changing of Japanese fishing practice. Under the pressure of increasing labour cost and fuel price, Japanese longliner began to catch bigeye tuna instead of previous yellow fin tuna and directly sent fresh catch to Japan's sashimi market with quickly refrigerated system (Butcher 2004: 222). By mid of 1960s, other longliner vessels from Taiwan and Korean also began to join the tuna fishing industry in Indian Ocean.

Following the Japanese and Indonesia fishery conflict and the (re-)making of the law of the sea under UN system, fishing activities within Indonesia water became more intensive and the volume of catch sharply increased between 1970s into early 1980s. Under the New Order regime, Indonesia pursued more aggressive policy on fishery to boost their economic growth. Several national fishing companies for longliner fishing was established mostly in joint venture arrangement with Japanese company as a strategy to overcome problem of capital and technology. PT. Perikanan Samudra (PSB) was established to work with Japanesse longliner company under the Banda Sea Agreement. Later, PT. East Indonesia was established with loans received from World Bank and Asian Development Bank and cooperation scheme with United Nations Development Program (UNDP) and Japan Government and entered a joint venture agreement with Japan's longliners, Nichiro Gyogyo Kaisha that owned $80 \%$ of capital share. As early in 1970s, fishing activities in Indonesia water began to use trawl and purse seine to increase the catches. There are at least three driven 
factor that contribute to massive transborder fishing activities in Indonesia waters. First is the steep demand for fishes to meet the population growth. If in 1850s, when modern fishing industry began in the Netherlands Indies, population in Java as the most dense areas was around 9,5 million people, but in early 1970s, Indonesia population had reached 130 million people. To compare with bigger scenes, in 1850s population in Southeast Asia state comprised around 40 million and in 1995 the number had reached 480 million people. Second is the export oriented policy of Indonesia's New Order regime to increase the amount of export commodity. Marine product became one of the priorities after Indonesia actively adopted the concept of archipelagic states. Thirdly is the competitive nature of fishing industry after the introduction of the CS regime and ongoing negotiation of fishing right under the EEZ regime. Although the second UN conference on 1973 failed to reach agreement regarding the limit of territorial sovereignty and fishing zone, in contrary soon after the conference most Southeast Asia and Pacific states had declared their EEZ. Burma, now Myanmar became the first declared its EEZ in April 1977, followed by Vietnam in May 1977, Cambodia and Philippines in 1978, Australian in 1979, Indonesia in 1981 and Malaysia in 1984. Inevitably, states inclined to be aggressive to exploit their marine natural resources. Thailand would be the first case suffering from this EEZ claim when their fishing catch sharply fell down in early 1980s. As consequence, Thai fishing vessels started to intrude into water of neighbouring states from Burma, Malaysia to Indonesia of which later classified as illegal fishing. Ironically, as the biological production circle would predict as the case of trepangs and shell-pearl, stock depletion gradually threatened the industry just in early 1980s.

In contrast to state-sponsored transborder fishing company of which operating in modern equipment, capital ownership and massive scale of catches, "traditional" Indonesian fishermen were marginalized from this modern-commercial fishing industry. On one hand, the joint venture fishing industry failed to provide adequate labour market that is able to absorb and integrate local fishermen. Technology had overcome problem of finding fishing grounds and securing safety navigation on the sea of which previously depend on the skill and expertise of local fishers. Most local fishermen were forced to occupy peripheral-small market demand either household consumption or domestic market. On the other hand, the expansion of Australia Fishing Zone (AFZ) had further limited fishing ground of Indonesian fishermen. Although MOU Box 1974 could be seen as international legal base to recognized Indonesian fishing tradition, yet the implementation proved to be problematic since the multi-interpretation prevail as the expansion of sea's function emerged. Below is the physical map of the MOU box 1974 that regulate fishing activity of Indonesian fishers (see detail on Figure 2).

In the late of 1970s and earlier 1980s, there were events that forced both Indonesia and Australia to further regulate activities in Timor and and Arafura Sea. First is the wave of refugee coming from prone-conflict countries such Vietnam, Sri Lanka, Iran and Afghanistan seeking for protection or even asylum seekers. The fall of Saigon following war in Indochina had ended Vietnam War in 1975. Soon in 1978, a second wave of Vietnam refugee flooded into neighbouring state including Indonesia. Referred as boat people, the floating boat people caused a humanitarian 
crisis. Indonesia provided Galang islands for Vietnam refugees. Despite United States and Canada, Australia also become friendly destination to refugees and asylum seeker and began to welcome Vietnam refugees. Later in 1980s and 1990s, influx of refugee seeking asylum in Australia continue as conflict broke in Sri Lanka, Afghanistan (Schetter, 2012:5) and Iran. They mostly used sea by boats to reach Australia while use Indonesia as the transit point. The image of Australia as "heaven destination" for immigrant inevitably flourished and established into a continuous "traditional route" of keep attracting immigrant. Since then, immigrant issues highly politicize into campaign agenda to win Australian domestic election (Phillips \& Spink, 2011:5). Public opinion in Australia shared the perception of threat coming from immigrants into Australian society as well as the conduct of human trafficking/smuggling of which received assistance from Indonesia fishers.

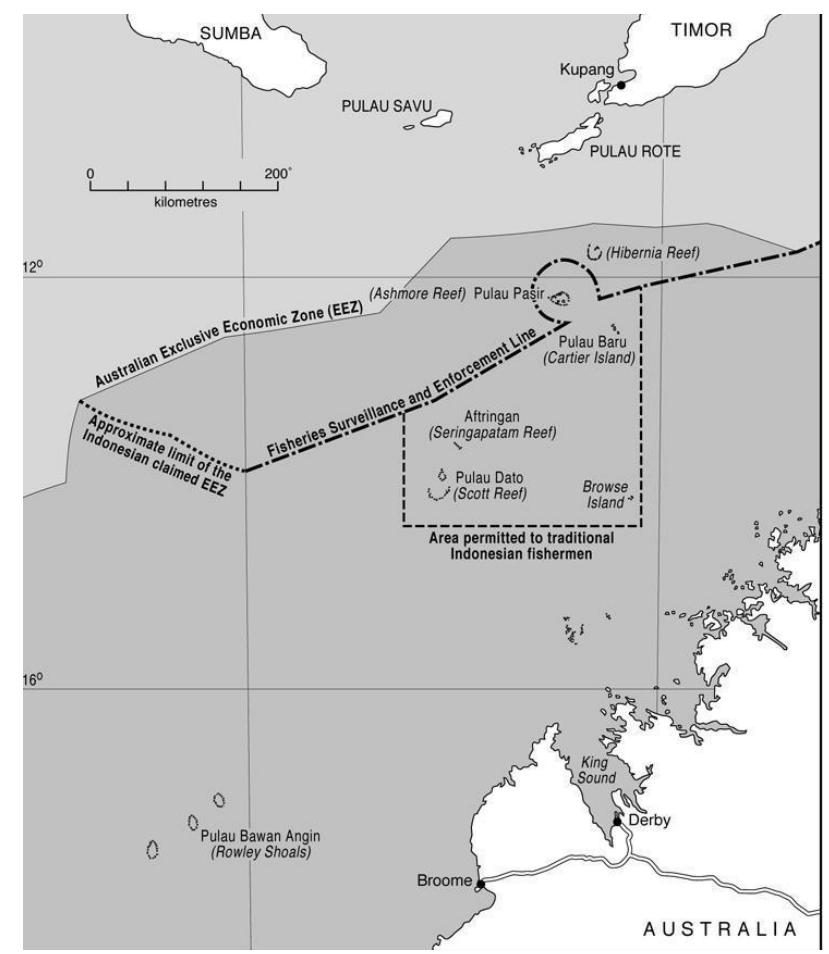

Figure 2. Transborder Map of MoU BOX 1974 Source : Fox \& Sen, 2002:9.

Second is Indonesia's military annexation to East Timor in 1975-1976, later know as independent Timor Leste in 1999. The annexation was claimed to prevent communism spreading after flower revolution broke up in home colonial state, Portugal. Motivated to establish a good neighbourhood relations, Indonesia and Australia entered serial of negotiation to delimit boundary on the sea.

Indonesia sought Australia's recognition to the inclusion of East Timor within its territorial sovereignty, while Australia sought opportunity to revive negotiation regarding oil reservation in Timor gap that had been ignored by Portugal (Djelantik, 2003). Between the years of 1962 - 1970, two consortium conducted serial geophysical survey in Timor sea \& Bonaparte Gulf that concluded the area to be petroliferous for oil and gas reserves (King, 2002:1-2). The first consortium consists of 
Arco Australia Ltd, Australia Aquitaine Pty.Ltd \& Esso Australian Ltd, while the second was established by Woodside Petroleum, Burma Oil Company, and AngloDutch Shell Oil Company.

Third is the depletion of marine stocks which push growing awareness to marine protection. On one hand, fishing into Australian water kept attracting Indonesian fishers as a respond to marine depletion in Indonesia water and continuous lucrative market. But, on the other hand, Australia declared Ashmore reef as Australian Natural Reserves on 16 August 1983 under National Park and Wildlife Conservation Act 1975 and become the subject of environmental protection. Initially, Ashmore reef was only annexed by the British in 1878. On 23 July 1931, Ashmore reef together with Cartier Island was transferred to Australia's possession of which later fell under the authority of Northern Territory. Trepang, trochus, turtles, sharks, seabirds are some of animal under protection and prohibit to be caught in this reef. Since then, illegal trespassing within AFZ and activities in Ashmore reef become highly scrutinize and boat burning became of the measure undertook by Australian Marine Patrol to deter future illegal practices. Even scholarly work by James Fox and Anthony Reid in 1992 had used the concept of illegal entry to categorize Indonesian fishermen detained in Australia prison for fishing in AFZ. In sum, these events had expanded activities in Timor Sea and Arafura Sea from initially fishing to passageway of immigrants, mineral exploration and exploitation, and environmental protection. The expanded function of Timor and Arafura Seas inevitability had made activities in the area subjected to further state regulations. Security measures are preferably employed to uphold law enforcement and defend territorial sovereignty of the state.

The resumption of diplomatic tension between Indonesia and Australia remains happening. In 2001, the Tampa incident retested bilateral relation of Indonesia-Australia. Indonesia's ferry carried around 433 people from Afghan and Sri Lanka seeking for asylum sank near Christmas Island. A Norwegian cargo ship, Tampa came to rescue and sailing to approach Chrismas Island. Yet, Australia authority denied authorization to anchor, while the ship's captain refused to turn back. After 6 days of floating on the sea, those asylum seekers were taken into Nauru Island and New Zealand. Since then and following the growing terrorist threat after 9/11 attack in 2001 and Bali Bomb 2002, mobility through Timor and Arafura Sea turns to further securitized. The graph below illustrates the fluctuation of boats arrivals in Australian water both in excised and non-excised place. It is interesting to note that the peak of boat arrivals prevails when diplomatic tension between Indonesia-Australia and domestic election in Australia take place. 


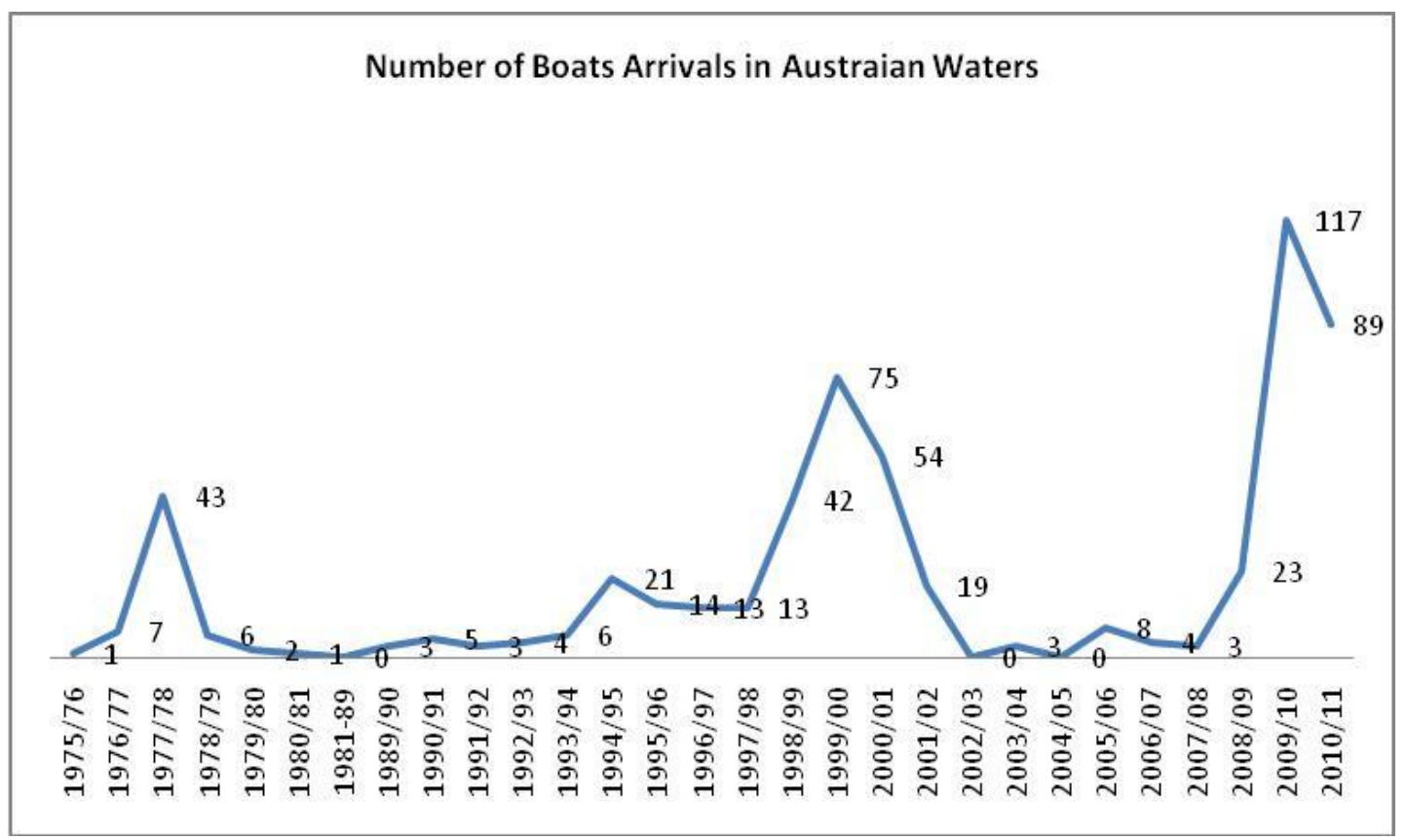

Figure 3. Number of Boats Arrivals in Australian Waters Source: Phillips \& Sink, 2011: 19.

In 2003, the death of Indonesian fishermen in Australian prison after guilty of illegal fishing near Ashmore reef invited strong protest from Indonesia. Table 1 below shows that Ashmore reef become the major landing used by boats arriving at Australian water. This inclination corroborates the continuation of route taken by transborder mobility in Timor and Arafura Sea since $18^{\text {th }}$ century.

\begin{tabular}{lcc}
\multicolumn{3}{c}{ Table 1. Major Landing of Boat Arrival in Australia } \\
\hline \multicolumn{1}{c}{ Major Landing } & $\mathbf{1 9 9 8 / 1 9 9 9}$ & $\mathbf{1 9 9 9 / 2 0 0 0}$ \\
\hline Ashmore Islands & 17 & 49 \\
Western Australia & 11 & 15 \\
Queensland & 3 & 0 \\
Torres Strait & 4 & 0 \\
Christmas Island & 3 & 10 \\
New South Wales & 3 & 0 \\
Darwin & 1 & 1
\end{tabular}

Source: Schloenhardt 2003:148-157

Later in June 2008, Indonesian television broadcasted the burning of Indonesia fishermen's boat after apprehended by Australian Marine Patrol following the official visit of Australia Prime Minister to Jakarta. The incident actually had took place two years earlier. The diplomatic tension was deescalated after Indonesia Ministry of Foreign Affairs officially regretted such broadcast. Some of this conflict episode confirmed the transformation of transborder fishing activity in Timor and Arafura Sea. The expanding function of the sea had created complexity in regulating transborder mobility including fishing. 


\section{Conclusion}

Transborder fishing activity in Timor and Arafura Sea has transformed significantly following the intrusion of state authority to expand their sovereignty rights and impose further regulation on the sea. It is the practice of territorialisation of the sea and the application of technology that pressures the transformation of trepang and shell-pearls industry from small scale and traditional into massive scale and modern fishing industry in $19^{\text {th }}$ and $20^{\text {th }}$ century of colonial period. Relying on distant market both Chinese and British, the industry received strong support from colonial state of which later triggered diplomatic tension between the Dutch and the British. The declaration of territorial water was one of the strategies employed by the Dutch to settle the conflict and presented new era of sea governing on the area. The depletion of marine stocks threatens the industry of trepang and shell-pearl to collapse in $20^{\text {th }}$ century, despite of nationalization of industry in Australia. For shell-pearl industry, it was also the invention of plastic which later close off the market demand. Soon, World War II that led to Japan occupation in Indonesia had temporarily destroyed the fishing industry in 1940s.

Post-war reconstruction and decolonization in Southeast Asia in the middle of 1940s had cemented new world order that bring second wave of transformation to transborder fishing in Timor and Arafura Sea. Post-colonial Indonesia, like other new post-colonial states in Southeast Asia, of which claiming of inheriting colonial administration shared strong view on sovereignty rights including territorial integrity on the sea. The introduction of state's right to CS and EEZ had been strongly adopted by Indonesia as well Australia under the new world governance of United Nations. Immediately in late 1960s and early 1970s, both Indonesia and Australia had declared and negotiated to delimit their maritime boundary. Even in 1982, Indonesia's proposal of the concept of archipelagic states had been succeed to win international recognition. The concept of archipelagic states was originally drawn to deter any unauthorized mobility on the sea for security purposes. Inevitably, the sea governance strengthens by employing more regulation to the mobility on the sea.

The sea turns to be the magnitude of state's interest and qualify to be national security. Any perceived threat to state's control on the sea is subject to security issue. While state-sponsored modern fishing industry are able to dominate fishing activity both on the access to fishing ground and the volume of catches, traditional fishing industry suffered from competition and push to struggle between stock depletion, low capital incentives and traditional fishing method. Problem of overfishing had increased practice of undocumented, unregistered and illegal fishing as post-colonial Indonesia struggle to balance its capacity between the desire of regulating fishing activity and the constraint of implement the regulation itself.

The continuous fishing activity of Indonesia fishermen into Australian Fishing Zone is essentially be local response against the domination of state authority in attempt to regulating transborder fishing activities. On one hand, confronting with massive scale and modern fishing company, local Indonesian fishermen failed to be 
integrated and marginalized into small scale traditional fishing activities to satisfy a steadily Chinese market. On the other hand, growing influx of refugee and asylum seeker had provided lucrative but illicit opportunity to engage with new form of transborder activity for additional income. Interestingly, the local fishers keep exploiting the antiquity of transborder fishing to justify their present activities, while the state constantly required local loyalty to abide with present cluster of sea ownership. Thus, transborder fishing activity has been transformed into liquid space (Houben: 2012) where the network chain of activity is determined by contested interest of certain identities. The Timor and Arafura Seas represent a transition space between geographically contained space and socio-economy construction of subjugated local people within state's control.

\section{Acknowledgment}

This paper has been presented in the International Seminar "Reviewing the Asia Pacific Maritime World: Globalization, Nationality, and Education Dilema”, on 18 September 2013. It was oganized by Master Program of History Faculty of Humanities, Diponegoro University.

\section{References}

Beare, M.J, Lorimer, P.D and Hynd, J.S. (1963) An Investigation of Tuna Long-ling in Japan and the Hawaiian Islands. Canbera: Fisheries Division, Department of Primary Industry.

Berndt, R.M. \& Berndt, C.H. 1954. Arnhem Land: Its History and Its People. Melbourne: Cheshire.

Butcher, John G. (2004) The Closing Frontier: A History of the Marine Fisheries of Southeast Asia c.1850-2000. Singapore: ISEAS Publication.

Djelantik, Sukawarsini (2003). The Failure of Indonesia Diplomacy? Indonesia's Political and Diplomatic Relations with Australia over East Timor. Australia: Department of Asian Studies and Languages, Flinder University of South Australia.

Fox, James J. \& Sen, Sevaly, "A Study of Socio Economic Issues Facing Traditional Indonesian Fishers who Access the MOU Box", A report for Environmental Australia, October 2002.

Fox, James J., \& Reid, A. (1992). Illegal Entry. Northern Territory University, Centre for Southeast Asian Studies.

Houben, Vincent (2012). Liquid Space, Southeast Asia and Beyond, paper presented at Crossroads Asia Conference on Figurations of Mobility, Berlin, 22-24 November.

King, Robert J. (2002). The Timor Gap, 1972-2002. Australia: Parliament of Australian, House of Representative accessed through www.aphref.aph.gov.au_house_ committee_jsct_timor_subs_sub43.pdf on 8 June 2013.

Martinez, Julia (2009). The Evolution of 'Malay' Labour Activism 1870-1947: protest among pearling crew in Dutch East Indies-Australia water, Transforming Cultures e-Journal 4 (2) 85.

Moore, Ronald (1994). The Management of the Western Australian pearling industry 1860 to the 1930s, The Great Circle 16 (2): 121-138 
Morwood, M.A. \& Hobbs, D.R. (1997). The Asian connection: preliminary report on Indonesian trepang sites on the Kimberley coast, NW Australia, Archaeology in Oceania 32:197-206.

Mullins, Steven (2001). Australian pearl-shellers in the Moluccas: confrontation $\mathcal{E}$ compromise a Maritime Frontier, The Great Circle 23 (2): 3-23

Phillips, Janet \& Spinks, Harriet (2011). Boat arrival in Australia since 1976. Parliament of Australia: Department of Parliamentary Services.

Russell, Denise (2004). Aboriginal-Makassan interactions in the eighteenth \& nineteenth centuries in northern Australia and the contemporary sea rights, Australian Aboriginal Studies 1: 3-17.

Schetter, Conrad (2012). Translocal Lives.Pattern of Migration in Afghanistan. In Crossroads Asia Working Paper Series, No.2.

Schloenhardt, Andreas (2003). Migrant smuggling: illegal migration \& organized crime in Australia $\mathcal{E}$ the Asia Pacific region. The Netherlands: Martinus Nijhoff Publisber.

Stacey, Natasha (1999). Boat to Burn: Bajo Fishing Activity in the Australian Fishing Zone. Dissertation. Faculty of Law, Business, and Arts. Northern Teritory University, Australia.

Wallace, Russel Alfred (1890). The Malaya Archipelago, the Land of Orang Utan and the Bird of Paradise: A Narrative of Travel with Studies of Man and Nature, $10^{\text {th }}$ edition. London: Macmillan.

"Timor Sea program amendment gets OK", in http://www.easttimorlawandjustice bulletin.com/2011/01/timor-sea-program-amendment-gets-ok.html on 8 June 2013. 